\title{
Sustainable Agriculture: Case Study in Barebbo Village, Bone Regency
}

\author{
Andika $^{1}$, Fitri Anugrah Sari ${ }^{1}$, Rosida Salam ${ }^{1}$, \\ Siti Nurazizah Jufri ${ }^{1}$, Ainim Paradita ${ }^{1}$ \\ ${ }^{l}$ Department of Agribusiness, Faculty of Agriculture, \\ Hasanuddin University, Indonesia
}

Corresponding Author: Andika

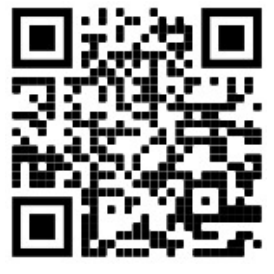

Article Info

\section{Article history:}

Received 07 January 2020

Received in revised form 14

January 2020

Accepted 24 January 2020

\section{Keywords:}

Sustainable agriculture

Ecological sustainability

Environment

\section{Abstract}

Ecological sustainability refers to the maintenance of the environmental order on earth so that its sustainability can be maintained. Three aspects must be considered to maintain the integrity of the environmental order, namely; carrying capacity, assimilative capacity and sustainable use of recoverable resources. Environmental development management is essential for ecosystem sustainability. Macroeconomic sustainability guarantees sustainable economic progress and encourages economic efficiency through structural and national reforms. Food security is defined as a condition for the fulfillment of food for households which is reflected in the availability of sufficient food, both in quantity and quality, safe, equitable, and affordable.

\section{Introduction}

The agricultural sector is a very important sector its role in the economy in most developing countries. we can see clearly from the role of the agricultural sector in accommodating the population and providing employment opportunities to the population. Agricultural development needs better attention, even though the priority of industrialization policy has been dropped, the agricultural sector can have the ability to produce a surplus. This happens when productivity is enlarged so as to produce higher farmer incomes and make it possible to save and accumulate capital. Improving the standard of living is obtained by farmers by increasing their income. To obtain high income they carry out various activities by developing various possibilities of other agricultural commodities (farm diversification) that are economically profitable if the agricultural land is possible. Income development outside farming (off-farm income) will also greatly help improve prosperity due to the limited potential of farming, various studies show that increasing agricultural sector income will be able to reduce the poverty rate of farmers (Sudarman, 2001).

Sustainable agriculture is agriculture whose management is based on meeting needs without compromising the needs of others. Sustainable development is development without compromising the interests of future generations. This concept is certainly in line with the concept of sustainable agriculture.

Saptana \& Ashari (2007) also differentiate into three main perceptions of sustainability. The first is an ecological definition of sustainability, which has a focus on biophysical processes and the continuous productivity of ecosystem functions. The second is the economic definition of sustainability, which mainly focuses on the long-term maintenance of the advantages of farming for its managers. The third is the social definition, which is aimed at 
the continuous fulfillment of the basic needs for food, shelter, security, justice, freedom, education, work, and recreation.

There are two concepts of sustainable development summarized from several literatures, namely the wealth approach and the mosaic approach. The prosperity approach states that development is said to be sustainable if development takes into account the value of natural capital and what is built so that the next generation can enjoy reserve assets no less than now. When sustainable development can be explained in terms of the "prosperity approach", the concept usually has clarity in ecological, economic and social components, this approach is the mosaic approach (Salikin, 2003).

This study aims to determine the sustainability of agricultural development by observing aspects of ecological sustainability, social sustainability, economic sustainability, political sustainability and sustainability of security and defense in Barebbo Village, Barebbo District.

\section{Methods}

This study uses a qualitative approach to determine the sustainability of agricultural development by observing aspects of ecological sustainability, social sustainability, economic sustainability, political sustainability and sustainability of security and defense in Barebbo Village, Barebbo District, Bone Regency, South Sulawesi. Data collection through interviews and observations. Data analysis is performed through data reduction, presentation and conclusion drawing.

\section{Results and Discussion}

Aspects of Ecology

Based on the opinions of some of the respondents we interviewed that most of the problems that occur in agricultural areas in Barebbo Village, Bone Regency, South Sulawesi Province are lacking or lack of irrigation water because of the water sources in the Village are far from agricultural land. Also in the village is usually hit by drought, it can be proven if we see some rice fields that have cracked. Apart from the lack of irrigation water, there are more people using chemical fertilizers compared to the use of organic fertilizers, because they consider that the use of chemical fertilizers produces more production besides the price is more affordable. So they are not aware that the use of chemical fertilizers that will interfere with many ecosystems, especially soil ecosystems. Therefore, it is necessary to understand the community about it through the counseling process or other matters. Because agriculture can be said. Ecologically sustainable if the activity must be able to maintain the integrity of the ecosystem, maintain the carrying capacity of the environment and the conservation of natural resources including biodiversity.

Ecological sustainability refers to the maintenance of the environmental order on earth so that its sustainability can be maintained. Three aspects must be considered to maintain the integrity of the environmental order, namely; carrying capacity, assimilative capacity and sustainable use of recoverable resources. Environmentally sound development management is essential for ecosystem sustainability. This can be done through the prevention of environmental pollution, rehabilitation, and restoration of damaged ecosystems and natural resources, increasing the production capacity of natural ecosystems and human development (Rozikin, 2012).

According to Cahyandito (2009) in principle, there are three main dimensions of sustainable development namely the environment, social and economy.

The following are the main problems that exist in each dimension of Ecological aspects One of the main theme/problems in this dimension is climate change. Over the past 50 years, it has been proven that global warming that we now feel is mainly due to human activities. 


\section{Social Aspects of Culture}

Based on the opinions of some of the respondents we interviewed about the socio-culture in the village, a small portion still exists but has begun to erode over time. According to one respondent, there are still people who do what is called 'mappamula' in the sense that before going down to planting or harvesting there will be smart people who will first plant or harvest by reciting mantras or holy verses before those who have land planted or harvested, this aims to produce abundant and good yields. in addition, social relations in the village of Barebbo, Bone Regency, South Sulawesi Province are still very intertwined, this can be seen from the existence of mutual cooperation, helping each other during harvesting and others. However, in terms of facilities and infrastructure are still inadequate, for example, there is still minimal road repair, but still lack of places of worship and educational facilities.

According to the Enquete Commission in Cahyandito (2009). The main problem that usually occurs in social aspects is the growth of the world population. In the last hundred years, population growth has been increasing rapidly especially in developing countries. It is estimated that the world population will increase to 7.8 billion people in 2025, of which 6.7 billion people live in developing countries. This increase in population is partly due to several factors, such as low levels of education, inadequate social security in the country concerned, culture and religion/beliefs, urbanization and discrimination against women.

\section{Economic aspect}

Based on the opinion of some of the respondents we interviewed, the economy in Barebbo Village is quite good, it can be seen from how much land owned by respondents, which reaches 3 ha. With a production of at least 100 sacks. However, in the sales process, they still cannot sell it themselves to the city. So those who buy their products are collectors or they bring their own warehouses in the village. The average proceeds they sell around 2500-3500 $\mathrm{kg}$.

The main problems in the economic dimension are global change and globalization. The point is a change in global environmental conditions (ecology), economic globalization, cultural change, and north-south conflict. Globalization that emerged since the 1990s, its presence can not be dammed and inevitably must be faced by every country. Advances in technology, communication and telecommunications, and transportation increasingly support the flow of globalization so that economic relations between countries and regions become very easy. Government support through the ease of customs increasingly encourages free trade In the era of globalization, all countries must prepare as tough as possible so as not to be crushed by a richer and more developed country (Cahyandito, 2009).

Macroeconomic sustainability guarantees sustainable economic progress and encourages economic efficiency through structural and national reforms. Three main elements for macroeconomic sustainability are economic efficiency, sustainable economic prosperity, and increasing equity and distribution of prosperity.

\section{Security and Political Aspect}

Food is a source of energy for all life and even food functions to maintain life itself because the energy needs of living things cannot be stopped, just as the energy needs for machinery. Thus, agricultural business is central to all dynamic activities in human life (Poti \& Popkin, 2011).

Easton interprets the term politics as "the process of authoritative allocation of values in society". this political understanding as an authoritative allocation of values marks the two stages of the formation of his political system theory. 
Attention to value as a commodity that is negotiated within society is the starting point for a political process. However, the process the allocation of values is not done arbitrarily or by anyone, but by community institutions that have the authority to do so. Meanwhile, Easton \& Hess (1962) states that there are 4 (four) assumptions that underlie the general thought building in studying a political system as follows. First, science requires a systematic construction or building to systematize facts or data found. Second, reviewers of political life must view the political system as a whole, not partial or separate parts of each other. Third, political system research consists of two types of data, namely psychological data and situational data.

Psychological data consists of personal characteristics and motivation of political participants. Situational data consists of all activities that arise due to environmental influences. The influence of this environment arises from the physical environment, nonhuman organic environment, and social environment. Fourth, the political system must be considered in a disequilibrium.

Food security is defined as the condition of fulfilling food for households reflected by the availability of sufficient, good food quantity and quality, safe, equitable and affordable. Indicators of the establishment of robust food security. The State (RI Government) has indeed made instruments (legal bodies and products) in the context of fulfilling the right to food, namely the Food Security Agency and Law No. 7 of 1996 concerning food, Law Number 23 of 1992 concerning health. Only in practice, the government is considered to have failed to fulfill the right to food and even issued economic policies that impoverish the people who have an impact on food insecurity (Arifin, 2007).

The implementation of public policies that have been produced by the political system is also heavily influenced by the environment, where this can shape the quality of the impact of policies that will appear later. The impact of policies, whether positive or negative, can be feedback that can be used as new inputs that are influenced by the environment. The policy of the enactment of Law Number 41 Years 2009 Regarding the Protection of Sustainable Agricultural Land (PLP2B), can be seen in the direction and purpose of the political politics of protecting the food agricultural land.

The urgent need for food fulfillment with efforts to conserve resources, the choice will have to be continued to find a balance between different kinds of interests. Therefore institutions and policies are needed at a level from village to global to ensure sustainable development. Food security is defined as a condition for the fulfillment of food for households which is reflected in the availability of sufficient food, both in quantity and quality, safe, equitable, and affordable.

\section{Conclusion}

Lack of understanding of the impact of excessive use of chemical fertilizers in the village of Barebbo causes the risk of land not to be ecologically sustainable because an agriculture can be said to be ecologically sustainable if the activity must be able to maintain ecosystem integrity, preserve the carrying capacity of the environment, and conservation of natural resources including biodiversity (biodiversity). In relation to the social relations of the people of Barebbo Village, it can still be said to be good, this can be seen from the frequent community activities in mutual cooperation for the benefit of the village. But this is inversely proportional to the cultural situation in the village, a small part of the culture is still being carried out, but has begun to erode over time. The economic situation in the village of Barebbo can be said to be quite good, this can be seen from the amount of land owned by respondents which reache 3 ha with a production of at least 100 sacks. 


\section{References}

Arifin, B. (2007). Diagnosis Ekonomi Politik Pangan dan Pertanian. Kemenkes, Republik Indonesia.

Cahyandito, M. F. (2009). The MIPS Concept (Material Input Per Unit of Service): A Measure for an Ecological Economy (No. 200901). Department of Management and Business, Padjadjaran University.

Easton, D., \& Hess, R. D. (1962). The child's political world. Midwest Journal of Political Science, 6(3), 229-246.

Poti, J. M., \& Popkin, B. M. (2011). Trends in energy intake among US children by eating location and food source, 1977-2006. Journal of the American Dietetic Association, $111(8), 1156-1164$.

Rozikin, M. (2012). Analisis Pelaksanaan Pembangunan Berkelanjutan di Kota Batu. Jurnal Review Politik, 2(02), 219-243.

Salikin, K. A. (2003). Sistem pertanian berkelanjutan. Kanisius.

Saptana, A. (2007). Pembangunan pertanian berkelanjutan melalui kemitraan usaha. Jurnal Penelitian Pengembangan Pertanian, 26(4), 123-130.

Sudarman. (2001). Teori Ekonomi Mikro. Pusat Penerbitan Universitas Terbuka. Jakarta. 